\title{
Bovine Virus Diarrhoea Virus in Semen from Acutely Infected Bulls
}

\author{
By E. Kommisrud ${ }^{I}$, T. Vatn ${ }^{I}$, J. R. Lang-Ree ${ }^{I}$ and T. Løken ${ }^{2,3}$ \\ ${ }^{1}$ Norwegian Cattle Association, Hamar, ${ }^{2}$ Central Veterınary Laboratory, Oslo, and ${ }^{3}$ Norwegian College of Vete- \\ rinary Medicıne, Oslo, Norway.
}

\begin{abstract}
Kommisrud, E., T. Vatn, J. R. Long-Ree and T. Løken: Bovine virus diarrhoea virus in semen from acutely infected bulls. Acta vet. scand. 1996, 37, 41-47. - The risk of spreading bovine virus diarrhoea virus (BVDV) from acutely infected animals to susceptible animals was investigated. Ten bulls from a herd with no previous history of BVDV were used. The bulls were demonstrated free from BVDV and such antibodies. Six of the bulls were inoculated intravenously with cytopathogenic virus, and 4 bulls were used as controls. Semen samples were collected during a perıod of 66 days after inoculation The samples were examıned for BVDV, and spermatological parameters were registered. Testes and epididymides were examined histologically post mortem. All inoculated bulls exhibited elevated temperatures between days 4 and 8 after inoculation, and BVDV antibodies were found in all of them on day 22. The control animals remained antibody negative. Non-cytopathogenic BVDV was isolated from semınal plasma from 2 bulls on day 7 after inoculation Semen volume was significantly reduced from week 6 after inoculation. Percent abnormal sperm cells decreased in the same penod No significant differences were observed in sperm density or percentage of live spermatozoa. No pathological changes were found in the testes or epididymides.
\end{abstract}

BVDV; acute; infection; transmission; semen.

\section{Introduction}

Bovine virus diarrhoea virus (BVDV) belonging to the genus Pestivirus in the family Flavlvirldae, is common all over the world. Ruminant pestiviruses, BVDV and the ovine border disease virus, may infect several species, including pigs. In Norway, pestivirus has been isolated from cattle and also sheep (Løken 1992), and antibodies have been demonstrated in goats (Løken 1992), pigs (Løken et al. 1991), reindeer (Krogsrud, personal communications) and elk (Vatn 1993), though, pestivirus is most common in cattle (Løken et al. 1991). Although the prevalence of BVDV-antibodies is lower in Norway than in most other European countries, $23 \%$ of Norwegian cattle herds are affected
(Nyberg et al. 1994). Persistently infected (p.i.) animals are the most important source of virus spread (Duffell \& Harkness 1985). However, BVDV may be transmitted to susceptible cows also with semen from p.i. bulls, as seroconversion has been registered after artificial insemination (AI) with such semen (Kirkland et al. 1994, Meyling \& Jensen 1988). Use of infected semen frequently results in reduced fertility due to impaired embryonic development and embryonic death, as shown by in vitro fertilization and in vitro culture (Guerin et al. 1992). AI with semen from a p.i. bull may also result in birth of p.i. calves (Kirkland et al. 1994, Meyling \& Jensen 1988). Semen from bulls that are acutely infected with BVDV has also been 
found to contain the virus 2 to 14 days after infection (Kirkland et al. 1991, Paton et al. 1989, Whitmore et al. 1978). Most acutely infected bulls have normal semen quality (Kirkland et al. 1991, Whitmore et al. 1978), although reduced sperm motility and density and an increased proportion of abnormal spermatozoa have been found (Kirkland et al. 1991, Paton et al. 1989).

In Norway bull calves for the AI-programme are inquired by the Norwegian Cattle Association at an age of 2 months. Occasionally, p.i. calves have entered the performance testing stations, especially before on-farm testing programs for BVDV were introduced in Norway. Their presence at the stations may have resulted in transient BVDV-infections in susceptible bulls. According to national standards, all bulls have been tested for BVDV at the performance testing stations and later at the AI-centres since 1985. These test results from the AI-centres have revealed seroconversion in a few bulls (Kommisrud \& Løken, unpublished data). Obviously, these bulls have been acutely infected after the testing at the performance testing stations, and they may have been transiently viremic during their early stay at the AI-centres.

The aims of the present study were to invest1gate the duration of the infectious period of semen from bulls acutely infected with BVDV, and to see whether virus isolation is possible from both raw and cryopreserved semen. Semen parameters during and after acute infection were examined, and the risk of spreading BVDV from transiently viraemic to antibody negative bulls was also evaluated.

\section{Materials and methods \\ Animals}

This study comprised 10 bulls, aged 13-16 months, which had not been used for natural mating. Three of the bulls were Norwegian Red Cattle (NRF), one was a cross between NRF and Charolais, 4 were crosses between NRF and Aberdeen Angus, and 2 were crosses between NRF and an old Norwegian breed. The animals were obtained from a dairy herd with no history of BVDV infection. Bulk milk samples from this herd showed no BVDV antibodies in an ELISA (Niskanen et al. 1989). The bulls were 14 days before inoculation demonstrated to be free from BVDV by inoculation of serum and frozen/thawed leucocytes on calf kidney cell culture (CK) (Lang-Ree et al. 1994, Løken 1990), and such neutralizing antibodies (titres<1:4) (Løken et al. 1982).

During the study the bulls were confined in an isolated barn, which was cleansed and disinfected, and where no other animals were housed. The bulls were placed in a row of stanchions without partitions. Two weeks preceding the period of study, the bulls were trained for semen collection with an artificial vagina. Three of the bulls refused to mount. These were incorporated in a control group of 4 bulls which were not inoculated with BVDV. The controls were kept in between the inoculated bulls. All inoculated bulls and controls were slaughtered 68 days after inoculation.

\section{Inoculation}

Six bulls were inoculated intravenously (day 0 ) with $5 \mathrm{ml}$ of supernatant fluid of frozen/thawed CK which was infected with a cytopathogenic BVDV isolate (MD 2157/66) (Løken 1990). The inoculum contained $10^{55}$ median tissue culture infectious doses per $100 \mu$ l of this pestivirus originally isolated from a Norwegian calf with mucosal disease.

\section{Clinical examinations}

During the first 2 weeks of the experimental period (days 0-14), all bulls were clinically examined once a day, including recordings of body temperature. From day 15 to day 66 such examinations were done 2 or 3 times a week. 
Serological and virological examinations

Blood for serum analyses was sampled on days $0,11,22,29,43$ and 66 , and serum was stored at $-20^{\circ} \mathrm{C}$ until tested. Two-fold serum dilutions were examined for neutralizing antibodies against the cytopathogenic NADL strain of BVDV (Løken et al. 1982). Lowest serum dilution was 1 in 4 . Neutralizing titres were expressed as the reciprocal of the highest serum dilution that prevented a cytopathic effect in one or both of the 2 replicate cultures.

Leucocytes from blood sampled on days 7 and 11 were prepared and examined for BVDV by isolation in CK (Lang-Ree et al. 1994). This procedure was performed by inoculation of 50 $\mu$ l samples onto CK in 96-well microtitre titre plates, and $200 \mu \mathrm{l}$ in 24 -well plates.

Raw semen was transported to the laboratory at +3 to $+5^{\circ} \mathrm{C}$ within $24 \mathrm{~h}$ after sampling, centr1fuged at low speed for $10 \mathrm{~min}$, and the cell fraction was washed twice in Earle's solution. Fractions of sperm cells and seminal plasma (supernatant) sampled on days $0,3,7,11,15$, $18,22,29,36,43,50,57$ and 66 , were stored at $-70^{\circ} \mathrm{C}$. Cryopreserved, TRIS-diluted semen from days $3,7,11,15,18,22$ and 29, was also examined for BVDV. The different semen preparations were diluted 1:10 in Earle's solution, $100 \mu 1$ inoculated onto CK in tubes, and incubated at $37^{\circ} \mathrm{C}$ for 7 days, then passaged in 96well microtitre plates for subsequent immunoenzymatic demonstration of non-cytopathogenic strains (Løken 1990). In addition, sperm cells and seminal plasma sampled on days 7 and 11 were similarly examined by inoculation of $200 \mu \mathrm{l}$ samples onto CK in 24-well microtitre plates.

\section{Spermatological and histological examinations} Semen was sampled from the 6 infected animals and one of the controls 3 times a week during the period from day 0 to 21 and twice a week from day 22 to 66 . From each ejaculate a native smear was prepared for counting of abnormal spermatozoa. In each smear 400 sperm cells were examined for abnormalities by phase contrast microscopy.

The ejaculate was treated in accordance with standard procedures of semen cryo-preservation. Volume and density of the ejaculate were recorded, before dilution with TRIS extender. Motility and percent live spermatozoa were determined by light microscopy. Diluted semen was filled into French mini straw, 27 mill sperms per straw, frozen in liquid nitrogen vapour, and stored in liquid nitrogen.

At slaughter on day 68 the testes and epididymides of the 7 bulls from which semen had been collected, were weighed and prepared for histological examination by fixing in Bouin's solution and stainıng with Hemalun Eosin.

The data on semen parameters were analysed by the general linear models procedure. The model used for analysis of variance for semen volume, density, progressive motılity and sperm abnormalities per collection period was as follows:

$$
\mathrm{y}_{1 \mathrm{jk}}=\mu+\mathrm{b}_{1}+\mathrm{a}_{\mathrm{j}}+\mathrm{e}_{\mathrm{ijk}}
$$

where:

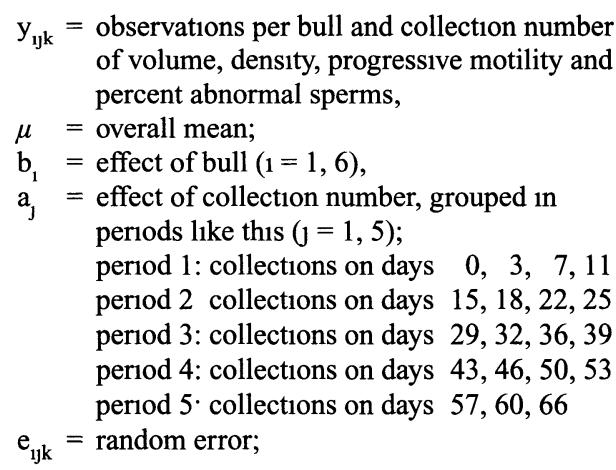

\section{Results}

\section{Clinical findings}

On day 3, three of the inoculated bulls showed slightly elevated temperature, between 39.2 and 
$39.5^{\circ} \mathrm{C}$. All inoculated bulls had elevated temperatures for a period of 1 to 4 days between days 4 and 8 . The peak temperature, between 40.2 and $41.7^{\circ} \mathrm{C}$, was measured on days 7 or 8 . The next day, the body temperature returned to normal in all bulls. Diarrhoea was observed in 2 bulls on day 1 , and coughing in 3 bulls on day 8. Apart from the above mentioned symptoms, none of the bulls showed any obvious signs of disease or lack of appetite.

None of the 4 control animals showed any signs of disease, and their body temperature remained normal.

\section{Serological findings}

Neutralizing antibodies against BVDV were found in 2 animals on day 11, and in all inoculated bulls on day 22 . The titres for one bull increased until day 29 , for 2 bulls until day 43 , and for the remaining 3 bulls until day 66 . The titres showed a distribution range from 4 to 256 on day 22, and from 256 to 512 on days 43 and 66 . The control animals were negative throughout the experiment.

\section{Virological findings}

Cytopathogenic virus was not found in any samples. Non-cytopathogenic BVDV was iso- lated from seminal plasma from 2 bulls on day 7 , at the inoculation in tubes only. No other samples were found positive for virus.

\section{Spermatological and histological findings}

Sperm volume was significantly lower in periods 4 and 5 than in period $1(\mathrm{p}<0.05)$. The percentage of abnormal sperm cells was significantly lower in periods 4 and 5 than in period 3 , and in period 4 than in period $2(\mathrm{p}<0.05)$. No statistical significant differences were observed in sperm density or percentage of live spermatozoa in different periods.

The average weights for right testes, right epididymides, left testes and left epididymides were $279.2 \mathrm{~g}, 24.4 \mathrm{~g}, 269,4 \mathrm{~g}$ and $24.8 \mathrm{~g}$, respectıvely Histological examination showed normal morphology of testes and epididymides in all bulls.

\section{Discussion}

Clinical signs following acute BVDV-infection are rare (Kirkland et al. 1991, Meyling \& Jensen 1988, Paton et al. 1989, Whitmore et al. 1978), making it difficult to detect acutely infected animals. In the present study clinical signs were mild and could easily have been overlooked if the animals had not been closely

Table 1 Least square means with SE (standard error) of spermatological findings related to time after inoculation.

\begin{tabular}{|c|c|c|c|c|c|c|c|c|}
\hline \multirow{2}{*}{$\begin{array}{c}\text { Period* } \\
\\
1\end{array}$} & \multicolumn{2}{|c|}{$\begin{array}{l}\text { Volume } \\
\mathrm{ml}\end{array}$} & \multicolumn{2}{|c|}{$\begin{array}{c}\text { Density } \\
\text { no sperm } \times 10^{3} / / \mathrm{mm}^{3}\end{array}$} & \multicolumn{2}{|c|}{$\begin{array}{c}\text { Motility } \\
\text { after dilution } \\
\text { with TRIS } \\
\%\end{array}$} & \multicolumn{2}{|c|}{$\begin{array}{c}\text { Abnormal sperm } \\
\%\end{array}$} \\
\hline & 5.68 & $\pm 0.36^{\mathrm{a}}$ & 816 & \pm 57.6 & 685 & \pm 2.40 & 8.8 & \pm 0.62 \\
\hline 2 & 5.08 & \pm 0.36 & 827 & \pm 57.6 & 67.7 & \pm 240 & 9.0 & $\pm 0.62^{\mathrm{d}}$ \\
\hline 3 & 5.23 & \pm 0.36 & 893 & \pm 57.6 & 66.5 & \pm 2.40 & 9.6 & $\pm 062^{\mathrm{e}}$ \\
\hline 4 & 458 & $\pm 036^{\mathrm{b}}$ & 866 & \pm 57.6 & 656 & \pm 2.40 & 7.2 & $\pm 0.62^{f}$ \\
\hline 5 & 4.27 & $\pm 0.43^{c}$ & 899 & \pm 68.5 & 67.9 & \pm 2.85 & 7.4 & $\pm 0.74^{\mathrm{g}}$ \\
\hline
\end{tabular}

* Period 1: days 0, 3, 7, 11. Period 2: days 15, 18, 22, 25. Period 3: days 29, 32, 36, 39. Period 4: days 43, 46, 50, 53. Period 5: days 57, 60, 66.

$\mathrm{a} / \mathrm{b}, \mathrm{a} / \mathrm{c}, \mathrm{d} / \mathrm{f}, \mathrm{e} / \mathrm{f}$ and $\mathrm{e} / \mathrm{g}$ are statistically different $(\mathrm{p}<005)$. 
monitored, thus suggesting that acute BVDVinfection seldom is detected in routine husbandry.

All inoculated bulls seroconverted, in contrast to the control animals which remained seronegative, even though they were in close contact to the inoculated ones. This finding corresponds with previous investigations, where no horizontal transmission of virus occured after experimental infections, neither when infection was induced by insemination (Meyling \& Jensen 1988) nor by rectal examination (Lang-Ree et al. 1994). Experimental infections may, however, not correspond completely with a natural infection. Recently, a report was given on a herd where an isolated part of the flock was claimed to have had no direct contact to p.i. animals throughout the period of study (Moerman et al. 1993). In this flock seroconversion was registered in several animals during a period of more than 2 years, and the source of infection was believed to be transiently viraemic cattle.

Virological results of the present study were in accordance with previous findings of BVDV in semen from bulls acutely infected with this virus (Kirkland et al. 1991, Paton et al. 1989, Whitmore et al. 1978). BVDV was isolated from seminal plasma only, from 2 of the 6 bulls on day 7 after inoculation. In other studies, however, virus has been isolated up to 14 days after infection (Kirkland et al. 1991, Paton et al. 1989), from both raw and cryopreserved semen (Kirkland et al. 1991). Variation in detection of BVDV in semen after acute infection may partly be due to a virucidal effect of semen, which reduces the infectivity of virus in a sample, and such influences the isolation result (Darcel \& Coulter 1976, Kahrs et al. 1980). The titre of virus in semen, as well as in tissue and blood, after acute BVDV-infection has been shown to be low (Kirkland et al. 1991). In the present study all semen preparations were frozen before inoculation on cell culture. This pro- cedure may have had a negative influence on the virus isolation by reducing a presumably low titre.

In this study, only non-cytopathogenic virus was isolated from semen, even though the inoculum has been shown to compose of cytopathogenic virus (Løken 1990). This may be due to the fact that cytopathogenicity is not a constant characteristic of a virus, but a property depending on genetic composition of the virus. Bes1des, the inoculum could have contained a noncytopathogenic BVDV at a low, undetected titre, which may, in contrast to the cytopathogenic virus, have replicated to a detectable titre during the transient infection.

BVDV replicates in the reproductive tract of bulls, as the virus has been isolated from semen several days after a viraemia (Kirkland et al. 1991, Paton et al. 1989). It has also been demonstrated that BVDV multiplies well in calf testes cell cultures (Brownlie 1990). Besides, BVDV has been found in ovaries from antibody positive heifers up to 25 days after an inoculation with the virus (Ssentongo et al. 1980). The described ovaritis was considered to be induced by a local immune response, which might have been caused by a local pestivirus infection. In the present study the collection of semen continued until 66 days after the inoculation. The purpose was to examine the time period of virus replication in cells of the genital tract and also the possibility of virus infection and replication in spermatogonia. As spermatogenesis takes approximately 7 to 8 weeks, virus replication in spermatogonia could induce transmission of virus with sperm cells several weeks after a viremia. However, the results from this study gave no indication of such replication and spread of this virus strain.

This work demonstrates that routine microscopic examination of semen may not raise suspicion of BVDV-infection in the bull. None of the 6 infected bulls showed any clear distur- 
bances in semen traits. Percent abnormal spermatozoa actually decreased during the observation period. This may partly be an effect of the bulls age as sperm abnormalities normally decrease between 1 and 2 years of age (AbdelRaoul 1965, Lagerlöf \& Cartquist 1961, Sekoni \& Gustavsson 1980). The fact that semen volume decreased during the study is difficult to explain. The collection frequency may have influenced negatively on the libido and semen volume in such young bulls.

The weights of the testes and epididymides were within normal range (Filseth 1969), which indicate that spermatogenesis was not affected by acute BVDV-infection.

\section{Conclusions}

The risk of transmitting BVDV through AI appears to be low, presuming that p.i. bulls are prevented from entering AI-centers. However, the findings of BVDV in semen from bulls which have been acutely infected, indicate that efforts should be done to prevent transient BVDV-infections in AI-bulls. The bulls should be demonstrated free from BVDV by serolog1cal and virological testing at the performance testing stations, kept in isolation for 3 weeks, and then retested. If any bulls are found to have seroconverted, another test should be carried out 3 weeks later in all companion bulls to exclude the possibility of horizontal transmission from the transiently infected bulls. When all bulls are demonstrated free from virus, and no seroconvertion has occured, the bulls can enter the AI-centre. With such a testing programme during the period prior to arriving at the AIcentres, all bull semen should be free from BVDV.

\section{Acknowledgments}

The authors wish to thank Dr. T. Steine, Norwegian Cattle Association, for assistance with statistical analyses, engineer Inger L Larsen and other techn1- cal staff at Central Veterinary Laboratory, Oslo, for their work with virus isolation and serology, and professor K. Andersen Berg, Norwegian College of Veterınary Medicine, Oslo, for the histological examınations.

\section{References}

Abdel-Raoul M Sexual behaviour and semen picture of bulls of the Swedish Red and White breed between the age of 9 and 15 months. Nord Vet.Med. 1965, 17, 318-322.

Brownlie $J$ The pathogenesis of bovine virus diarrhoea virus infections Rev. sci. tech. Off int. Ep1z 1990, 9, 43-59.

Darcel CleQ, Coulter FH IBR virus neutralızıng substance in bull seminal fluid and its removal prior to attempts at virus isolation from semen Can. vet. J. 1976, 17, 318-320

Duffell SJ, Harkness JW Bovine virus diarrhoea-mucosal disease infection in cattle. Vet. Rec. 1985, $117,240-245$.

Filseth $O$ Undersøkelse av kjønnsorganer på sønnegrupper etter semınokse. (Investigation of gen1tals of male offspring of donor sires). Buskap og Avdrått 1969, 1, 23.

Guerin B, Chauffaux St, Marquant Le Guienne B, Allietta $M$, Thibier $M$. IVF and IV culture of bovine embryos using semen from a bull persistently infected with BVDV. Theriogenology 1991, 37, 217.

Kahrs RF, Glbbs EPJ, Larsen RE The search for v1ruses in bovine semen, a review. Theriogenology 1980, 14, 151-165.

Kirkland PD, Mackintosh SG, Moyle A. The outcome of widespread use of semen from a bull persistently infected with pestivirus Vet Rec 1994, 135, 527-529.

Kirkland PD, Richards SG, Rothwell JT, Stanley DF. Replication of bovine viral diarrhoea virus in the bovine reproductive tract and excretion of virus in semen during acute and chronic infections. Vet. Rec 1991, 128, 587-590.

Lagerlof N, Cartquist $H$. The semen of boars of the Yorkshire breed between the ages of five to nine months. Proceedings 4th Int Congress on Animal Reproduction (Hague) 1961, 4, 818-821.

Lang-Ree JR, Vatn T, Kommisrud E, Løken T Transmission of bovine viral diarrhoea virus by rectal examination Vet. Rec 1994, 135, 412-413.

Løken $T$ Pestıvirus infections in Norway Epidemiological studies in goat. J. comp. Path. 1990, 103, $1-10$. 
Løken $T$ Pestıvirus infections in ruminants in Norway Rev sc1. tech. Off. int. Epız 1992, 11, 895899

Løken T, Hyllseth B, Larsen HJ Border disease in Norway Serological examination of affected sheep flocks. Acta vet. scand 1982, 23, 46-52.

Løken T, Krogsrud J, Larsen IL Pestvirus infections in Norway. Serological investigations in cattle, sheep and pigs Acta vet. scand. 1991, 32, 27-34

Meyling A, Jensen AM Transmission of bovine virus diarrhoea virus (BVDV) by artificial insemination (AI) with semen from a persistently-infected bull. Vet. Microbiol 1988, 17, 97-105.

Moerman A, Straver PJ, de Jong MCM, Quak J, Baanvinger Th, van Oirschot JT A long termepidemiological study of bovine viral diarrhoea infections in a large herd of dairy cattle. Vet Rec 1993, 132, 622-626.

Niskanen R, Alentus $S$, Larsson B, Junttı $N$ Evaluation of an enzyme-linked immunosorbent assay for detection of antibodies to bovine virus diarrhoea virus in milk. J vet. Med. 1989, B36, 113118.

Nyberg O, Krogsrud J, Waage $S$ Status for prosjektet kontroll/bekjempelse av bovin virusdiaré/mucosal disease. (The present situation for control of bovine virus diarrhoea/mucosal disease in Norway.) Norsk Vet.-T 1994, 106, 38-41.

Paton DJ, Goodey R, Brockman S, Wood L Evaluation of the quality and virological status of semen from bulls acutely infected with BVDV Vet. Rec. 1989, 124, 63-64.

Sekonı G, Gustavsson BK The insidence of sperm abnormalities in dairy bulls and effects of age and season Proceedings 10th Int Congress on Anımal Reprod and AI (Madrid) 1980, 3, 284

Ssentongo YK, Johnson RH, Smith JR Association of bovine viral diarrhoea-mucosal disease virus with ovaritis in cattle. Aust vet J 1980, 56, 272273.

Vatn T BVD-undersøkelse på elg (BVD-registrations in elk) Norsk Vet -T. 1993, 105, 841.
Whitmore HL, Gustafsson BK, Havaresht P, Duchateau $A B$, Mather $E C$ Inoculation of bulls with bovine virus diarrhoea virus: Excretion of virus in semen and effects on semen quality Theriogenology 1978, 9, 153-163.

\section{Sammendrag}

Bovint virus diaré virus $\imath$ sced fra akutt infiserte okser

Faren for å spre bovint virus diaré virus (BVDV) fra akutt infiserte dyr t1l mottakelige dyr er undersøkt $\mathrm{T}_{1}$ okser som var vist å være frı for BVDV og tılsvarende antıstoffer ble brukt 1 undersøkelsen. Seks okser ble inokulert intravenøst med cytopathogent virus, mens 4 okser ble brukt som kontroller. Sædprøver ble samlet 1 perioden fra inokulasjon t1l 66 dager etter inokulasjon. Sædprøvene ble undersøkt for forekomst av BVDV, og spermatologiske parametre ble registrert. Testes og epıdidymides ble undersøkt histologisk post mortem.

Alle inokulerte okser fikk forhøyet kroppstemperatur mellom dagene 4 og 8 etter inokulasjon, og BVDV antistoffer ble funnet hos alle på dag 22. Kontrolldyrene forble antıstoff negative 1 hele forsøksperioden. BVDV ble 1solert fra sædplasma 1 ufortynnete sædprøver hos 2 okser på dag 7 etter inokulasjonen. Sædvolumet ble sıgnifikant redusert fra uke 6 etter inokulasjonen Prosent abnormale spermier ble redusert 1 den samme perioden. Ingen signifikante forskjeller ble observert når det gjelder spermiekonsentrasjon eller prosent motıle spermier. Det ble ikke påvıst patologiske forandrınger 1 testes eller epıd1dymides

Dette arbeıdet viser at faren for overførıng av BVDV med sæd fra akutt infiserte okser er liten. Man bør l1kevel gjennomføre et kontrollprogram for BVDV som hındrer både p.1 og akutt infiserte okser 1 å settes inn på oksestasjonene.

(Accepted October 10, 1995)

Reprınts may be obtained from Elısabeth Kommısrud, Norsk Rødt Fe, Store Ree, N-2310 Stange, Norway 